\title{
Micro- and nano-size hydrogrossular-like clusters in pyrope crystals from ultra-high-pressure rocks of the Dora-Maira Massif, western Alps
}

\author{
Charles A. Geiger ${ }^{1}$. George R. Rossman ${ }^{2}$
}

Received: 9 December 2019 / Accepted: 29 April 2020 / Published online: 2 June 2020

(c) The Author(s) 2020

\begin{abstract}
The supracrustal metamorphic rocks of the Dora-Maira Massif, western Alps, have been intensively studied. Certain ultrahigh-pressure lithologies contain coesite and nearly end-member composition pyrope, $\mathrm{Mg}_{3} \mathrm{Al}_{2} \mathrm{Si}_{3} \mathrm{O}_{12}$, making this locality

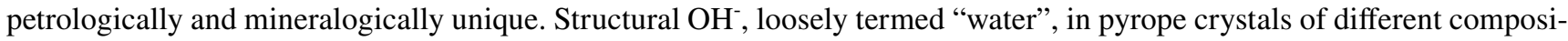
tion has been investigated numerous times, using different experimental techniques, by various researchers. However, it is not clear where the minor $\mathrm{OH}^{-}$is located in them. IR single-crystal spectra of two pyropes of composition $\left\{\mathrm{Mg}_{2.79}, \mathrm{Fe}^{2+}{ }_{0.15}\right.$, $\left.\mathrm{Ca}_{0.04}\right\}_{\Sigma 2.98}[\mathrm{Al}]_{2.02}(\mathrm{Si})_{2.99} \mathrm{O}_{12}$ and $\left\{\mathrm{Mg}_{2.90}, \mathrm{Fe}^{2+}{ }_{0.04}, \mathrm{Ca}_{0.02}\right\}_{\Sigma 2.96}[\mathrm{Al}]_{2.03}(\mathrm{Si})_{3} \mathrm{O}_{12}$ were recorded at room temperature (RT) and $80 \mathrm{~K}$. The spectra show five distinct $\mathrm{OH}^{-}$bands located above $3600 \mathrm{~cm}^{-1}$ at RT and seven narrow bands at $80 \mathrm{~K}$ and additional fine structure. The spectra were curve fit and the $\mathrm{OH}^{-}$stretching modes analyzed and assigned. It is argued that $\mathrm{OH}^{-}$is located in microscopic- and nano-size $\mathrm{Ca}_{3} \mathrm{Al}_{2} \mathrm{H}_{12} \mathrm{O}_{12}$-like clusters. The basic substitution mechanism is the hydrogarnet one, where $\left(\mathrm{H}_{4} \mathrm{O}_{4}\right)^{4-} \Leftrightarrow\left(\mathrm{SiO}_{4}\right)^{4-}$, and various local configurations containing different numbers of $\left(\mathrm{H}_{4} \mathrm{O}_{4}\right)^{4-}$ groups define the cluster type. The amounts of $\mathrm{H}_{2} \mathrm{O}$ range between 5 and $100 \mathrm{ppm}$ by weight, depending on the IR calibration adopted, and are variable among crystals. Hydrogrossular-like clusters are also present in a synthetic pyrope with a minor Ca content grown hydrothermally at $900{ }^{\circ} \mathrm{C}$ and $20 \mathrm{kbar}$, as based on its IR spectra at RT and $80 \mathrm{~K}$. Experiment and nature are in agreement, and $\mathrm{OH}^{-}$groups are partitioned into various barely nano-size hydrogrossular-like clusters. This proposal is new and significant mineralogical, petrological, and geochemical implications result. Ca and proton ordering occur. Hypothetical "defect" and/or coupled-substitution mechanisms to account for structural $\mathrm{OH}^{-}$are not needed to interpret experimental results. $\mathrm{OH}^{-}$incorporation in pyrope of different generations at Dora-Maira is discussed and $\mathrm{OH}^{-}$could potentially be used as an indicator of changing $P_{\mathrm{H}_{2} \mathrm{O}}\left(a_{\mathrm{H}_{2} \mathrm{O}}\right)-T$ conditions in a metamorphic cycle. Published experimental hydration, dehydroxylation, and hydrogen diffusion results on Dora-Maira pyropes can now be interpreted atomistically.
\end{abstract}

Keywords Pyrope $\cdot$ IR spectroscopy $\cdot \mathrm{H}_{2} \mathrm{O} \cdot$ Hydrogrossular nano clusters $\cdot$ High pressure $\cdot$ UHP metamorphism

Communicated by Timothy L. Grove.

Electronic supplementary material The online version of this article (https://doi.org/10.1007/s00410-020-01693-1) contains supplementary material, which is available to authorized users.

Charles A. Geiger

ca.geiger@sbg.ac.at

1 Department Chemistry and Physics of Materials, Section Materials Science and Mineralogy, Salzburg University, Jakob Haringer Strasse 2a, A-5020 Salzburg, Austria

2 Division of Geological and Planetary Sciences, California Institute of Technology, Pasadena, CA 91125-2500, USA

\section{Introduction}

Estimates of the amount of $\mathrm{H}_{2} \mathrm{O}$ held in Earth's mantle range between 0.5 and 5.5 oceans worth (Hirschmann et al. 2005). Regardless of the exact quantity, such magnitudes are of global geochemical and geophysical significance. The key reservoir for $\mathrm{H}_{2} \mathrm{O}$ in the upper mantle lies in the small amounts of $\mathrm{OH}^{-}$that are structurally bound in the nominally anhydrous minerals (NAMs) olivine, orthopyroxene, clinopyroxene and garnet, as shown by Bell and Rossman (1992a). These four silicates can hold small concentrations of $\mathrm{OH}^{-}$that, when integrated over their volumes contained in the upper mantle, give rise to such large-scale, global amounts of water. Much research has concentrated on investigating the concentration of $\mathrm{OH}^{-}$in 
these phases (e.g., Bell et al. 1995; Ingrin and Skogby 2000; Rossman 2006; Peslier 2010). The presence of $\mathrm{OH}^{-}$ in silicates, and here garnet, is of key mineralogical, petrological, geochemical, and even rheological significance (e.g., Bell and Rossman 1992a, b; Xu et al. 2013; Zhang et al. 2019; Geiger and Rossman 2020a, b). Great strides have been made in several scientific areas and a good deal has been learned with respect to water in NAMs. Surprisingly, on the other hand, understanding is still lacking in some most fundamental questions.

Take the high-pressure garnet pyrope, ideal end-member formula $\left\{\mathrm{Mg}_{3}\right\}\left[\mathrm{Al}_{2}\right]\left(\mathrm{Si}_{3}\right) \mathrm{O}_{12}$. There have been numerous investigations on the nature of its $\mathrm{OH}^{-}$. IR singlecrystal spectroscopy, which is generally the experimental method of choice for documenting the presence of $\mathrm{OH}^{-}$in minerals, has been used in most of the investigations on both natural and synthetic pyrope crystals (Rossman et al. 1989; Geiger et al. 1991; Khomenko et al. 1994; Hösch and Langer 1996; Wang et al. 1996; Bell and Rossman 1992b; Lu and Keppler 1997; Withers et al. 1998; Matsyuk et al. 1998; Geiger et al. 2000; Blanchard and Ingrin 2004a, b; Mookerjee and Karato 2010; Xu et al. 2013; Schmädike et al. 2015; Gose and Schmädicke 2018; Geiger and Rossman 2018; Schmädicke and Gose 2019). The hydrogarnet substitution, namely $\left(\mathrm{H}_{4} \mathrm{O}_{4}\right)^{4-} \Leftrightarrow\left(\mathrm{SiO}_{4}\right)^{4-}$ or $(4 \mathrm{H})^{+} \Leftrightarrow(\mathrm{Si})^{4+}$, as proposed several times (Geiger et al. 1991; Withers et al. 1998; Mookerjee and Karato 2010), and later argued for, based on an IR spectral analysis of different garnet species measured at different temperatures (Geiger and Rossman 2018), is probably operating for synthetic end-member composition pyropes grown hydrothermally in the laboratory. The hypothetical garnet component would be $\mathrm{Mg}_{3} \mathrm{Al}_{2}\left(\mathrm{H}_{4} \mathrm{O}_{4}\right)_{3}$.

However, the situation for natural garnets that are compositionally more complex substitutional solid solutions, and whose IR spectra are mostly different from their synthetic end-member crystal analogues, is completely unclear. Here, various defect $\mathrm{OH}^{-}$substitutional mechanisms have been considered and proposed including, for example, $\left\{2 \mathrm{H}^{+} \Leftrightarrow \mathrm{Ca}^{2+}\right\}$ and $\left[3 \mathrm{H}^{+} \Leftrightarrow \mathrm{Al}^{3+}\right]$ in the case of grossular (e.g., Basso et al. 1984; Birkett and Trzcienski 1984; Basso and Cabella 1990), which has been most intensively studied. In addition, coupled substitutional mechanisms such as $\left\{\mathrm{Li}^{+}-\mathrm{H}^{+} \Leftrightarrow \mathrm{Mg}^{2+}\right\},\left[\mathrm{Mg} / \mathrm{Fe}^{2+}-\mathrm{H}^{+} \Leftrightarrow\right.$ $\left.\mathrm{Al} / \mathrm{Fe}^{3+}\right],\left(\mathrm{B}^{3+}-\mathrm{H}^{+}\right) \Leftrightarrow\left(\mathrm{Si}^{4+}\right)$ and $\left(\mathrm{Al}^{3+}-\mathrm{H}^{+}\right) \Leftrightarrow\left(\mathrm{Si}^{4+}\right)$ have been proposed for pyrope and other garnets (e.g., Kühberger et al 1989; Khomenko et al. 1994; Lu and Keppler 1997; Reynes et al. 2018). The substitutions $\mathrm{H}^{+}+\mathrm{Al}^{3+}=$ $\mathrm{Si}^{4+}$ and $\mathrm{H}^{+}+\mathrm{B}^{3+}=\mathrm{Si}^{4+}$ do occur in other mineral structures (Rossman 1986). However, none of these mechanisms has ever, to the best of our knowledge, been demonstrated in the case of garnet. Because mantle pyropes are compositionally complex, considerable research has focused on compositionally simpler pyrope from the ultrahigh-pressure (UHP) Dora-Maira Massif located in the western Alps of Italy.

Supracrustal rocks of this Massif, containing coesite and nearly end-member pyrope, have been of great interest. Some garnet crystals, found in whiteschists and quartzites from the Brossasco-Isasca Unit, have about a 98 mole $\% \mathrm{Mg}_{3} \mathrm{Al}_{2} \mathrm{Si}_{3} \mathrm{O}_{12}$ component. The rocks of Dora-Maira and their paleo-geologic, -petrologic and -geochemical conditions have been investigated numerous times (e.g., Chopin 1984; Schertl et al. 1991; Avigad 1991; Sharp et al. 1993; Chopin and Schertl 1999; Simon and Chopin 2001; Compagnoni and Hirajima 2001; Zechmeister et al. 2007; Ferrando et al. 2009; Gauthiez-Putallaz et al. 2016; Groppo et al. 2019). The IR spectra of various composition pyropes have been measured and studied as well (Rossman et al. 1989; Lu and Keppler 1997; Guastoni et al. 2001; Blanchard and Ingrin 2004a, b; Geiger and Rossman 2018). The common-sense reasoning was that $\mathrm{OH}^{-}$in them could be structurally similar to $\mathrm{OH}^{-}$found in synthetic end-member pyrope. However, the observed IR-active $\mathrm{OH}^{-}$stretching modes in the spectra are completely different, in terms of number and energy, between both types of crystals. The conclusion was that $\mathrm{OH}^{-}$is incorporated differently in the natural crystals compared to the synthetics and, thus, apparently not through the hydropyrope component, $\mathrm{Mg}_{3} \mathrm{Al}_{2}\left(\mathrm{H}_{4} \mathrm{O}_{4}\right)_{3}$, substitution. The $\mathrm{OH}^{-}$in the Dora-Maira pyropes has been termed as defect in nature (Lu and Keppler 1997; Blanchard and Ingrin 2004a,b). The reason(s) for the difference in the spectra of natural versus synthetic crystals is(are) all very puzzling and the problem has stumped the mineral-science community for about 30 years.

We are investigating further the nature of small amounts of structural $\mathrm{OH}^{-}$in various end-member garnet species as well as in intermediate solid-solution compositions (Geiger and Rossman 2018; Geiger and Rossman 2020a, b; Geiger and Rossman unpub.). As a part of this greater research effort, and based on our findings and analysis up to now, we studied again the IR spectra and the nature of $\mathrm{OH}^{-}$of the previously much-investigated, but poorly understood, pyrope from Dora-Maira. The emphasis of our analysis is on atomic vibrational behavior and crystal chemistry and not on "defect" considerations. We think previous research studies have been "barking up the wrong tree" so to speak. Our conclusions are fundamentally new, but, when interpreted together in light of our recent work on $\mathrm{OH}^{-}$in garnet, are quite logical and common sense. For the first time, they allow different published experimental results to be interpreted in a new atomistic light. In addition, petrologic information relating to the complex metamorphic history of the rocks at Dora-Maira can potentially be obtained. 


\section{Samples used for study and experimental methods}

Two Dora-Maira pyropes, Mas-2b from Masueria, Italy, and Ch-2, unknown locality, were investigated and are from the personal collection of C.A.G. via C. Chopin. A geologic map of the Massif, showing localities, is presented in Simon and Chopin (2001). The same crystals have been studied before using both an IR microscope and in the spectrometer itself using metal apertures with various size pinholes (Geiger and Rossman 1994; Geiger and Rossman 2018). Ch-2 is colorless and transparent to the eye, whereas Mas-2b shows a pinkish tint (Fig. 1). IR single-crystal spectra were collected on both garnets in the energy range between 3000 and $4000 \mathrm{~cm}^{-1}$ at room temperature (RT) and at different low temperatures ultimately down to $80 \mathrm{~K}$. The sample preparation method and experimental IR setup have been described (Geiger and Rossman 2018). In addition, the RT and $80 \mathrm{~K}$
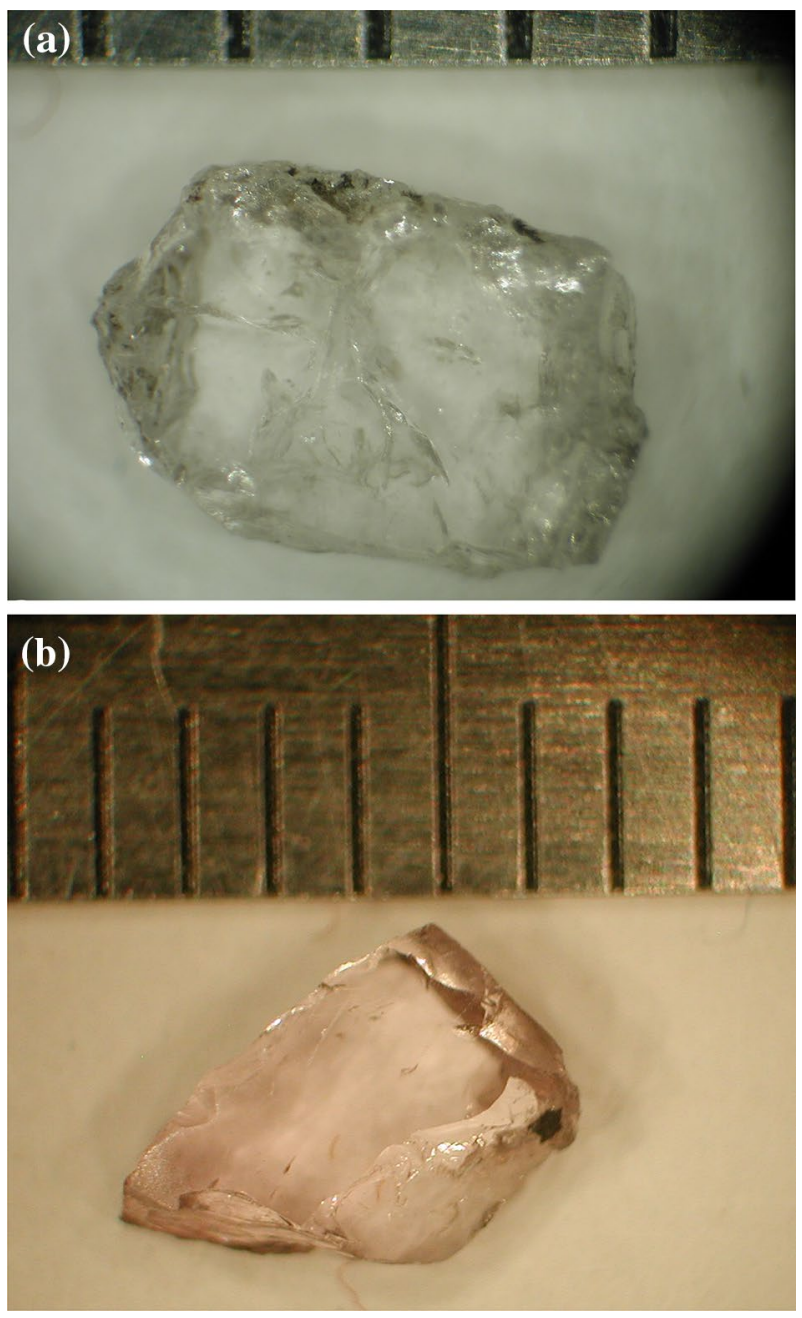

Fig. 1 Pyrope crystals from the Dora-Maira Massif, western Alps, Italy. a Colorless crystal, Ch-2 and b Pinkish crystal, Mas-2b. The scale is in $\mathrm{mm}$ spectra of a synthetic pyrope (P-27) synthesized from a gelstarting material are also analyzed. This garnet and its RT spectrum are discussed in Geiger et al. (1991). We use these results as well as unpublished IR data recorded at $80 \mathrm{~K}$ from their study. Spectral results were curve fit using the WiRE program of Renishaw that is part of their Raman systems (see Geiger and Rossman 2020a, b).

Chemical analyses were obtained on the two natural pyropes at Caltech with a JEOL JXA-8200 electron microprobe interfaced with Probe Software, Inc.'s program "Probe for EPMA" and operated in focused beam mode at $15 \mathrm{kV}$ and $15 \mathrm{nA}$. Quantitative elemental microanalyses were processed with the CITZAF correction procedure (Armstrong 1995). X-ray fluorescence micro-analyses were conducted on the synthetic pyrope (P-27) sample with an INAM Expert 3L tabletop XRF under helium purge with a Ti target using INAM's built-in fundamental parameter software. The composition of synthetic crystal, P-27, was only measured using these XRF methods, as the crystal was later lost during preparation of the microprobe mount.

\section{Results}

\section{IR spectra and microprobe results}

Infrared data for the three studied garnets (Ch-2, Mas-2b, $\mathrm{P}-27)$ can be found in supplementary files $1-4$. The microprobe and micro-XRF results are summarized in Tables 1 and 2. The anhydrous crystal-chemical formulae of the Dora-Maira garnets were calculated, using the formulation of Locock (2008), giving $\left\{\mathrm{Mg}_{2.79}, \mathrm{Fe}^{2+}{ }_{0.15}, \mathrm{Ca}_{0.04}\right\}_{2.98}[\mathrm{Al}]_{2.02}$ $(\mathrm{Si})_{2.99} \mathrm{O}_{12}$ for Mas-2b and $\left\{\mathrm{Mg}_{2.90}, \mathrm{Fe}^{2+}{ }_{0.04}, \mathrm{Ca}_{0.02}\right\}_{2.96}[\mathrm{Al}]_{2.03}$ (Si) ${ }_{3.00} \mathrm{O}_{12}$ for $\mathrm{Ch}-2$. The latter has, upon renormalizing, about $98 \%$ pyrope component making it, as best we know, one of the most pyrope-rich garnets found to date on Earth.

The IR single-crystal spectra of pyrope Mas-2b, in the energy range of the $\mathrm{OH}^{-}$stretching vibrations, at RT and $80 \mathrm{~K}$ are shown in Fig. 2a. The spectra of sample Ch-2 are similar in appearance and, therefore, not shown here. The RT spectrum shows five main $\mathrm{OH}^{-}$bands with peak maxima at $3602,3618,3641,3651$, and $3660 \mathrm{~cm}^{-1}$. The latter mode shows a clear shoulder on its high-energy flank. Previous measurements on these garnets (Geiger and Rossman 1994; Geiger and Rossman 2018) show that the same $\mathrm{OH}^{-}$band pattern is obtained at different locations on the crystal platelets and that the mode intensities remain nearly the same. No significant zoning in $\mathrm{H}_{2} \mathrm{O}$ content is present.

The spectrum recorded at $80 \mathrm{~K}$ shows a narrowing of the bands and better spectral resolution. New modes occur, which were not observed before. The five bands observed at RT shift slightly to higher wavenumbers at the lower temperature and have peak maxima at 3604, 3622, 3644, 3654, 


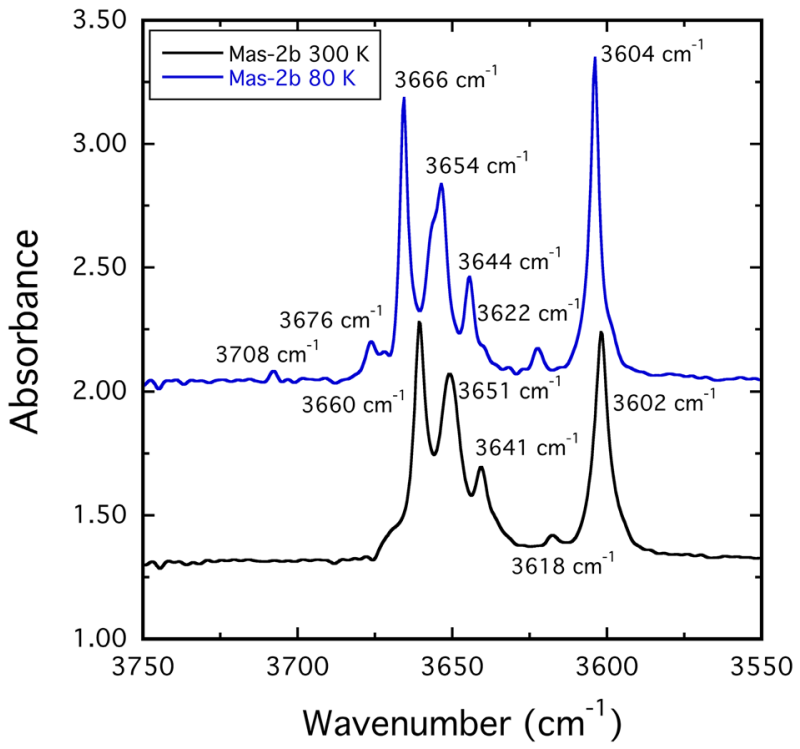

Fig. 2 a IR single-crystal spectra at room temperature (RT) and $80 \mathrm{~K}$ of pyrope, Mas- $2 b$, from the Dora-Maira Massif, western Alps, Italy. Both spectra were collected in the cooling stage at the same measuring spot. The crystal thickness is $2.308 \mathrm{~mm}$

and $3666 \mathrm{~cm}^{-1}$. Two weak modes at 3676 and $3708 \mathrm{~cm}^{-1}$ can also be observed. There are, in addition, weak shoulders on the low-energy flanks of the bands at 3604 and $3644 \mathrm{~cm}^{-1}$ and a noticeable shoulder on the high-energy flank of the band at $3654 \mathrm{~cm}^{-1}$. The RT spectrum can be fit with six bands and the spectrum recorded at $80 \mathrm{~K}$ with nine bands (more modes are also possible, for example, the very weak shoulder on the high energy flank of the band at $3604 \mathrm{~cm}^{-1}$ ) (Supplementary Fig. 2b and c).

The IR spectra of the synthetic pyrope synthesized from a gel-starting material (P-27) at RT and $80 \mathrm{~K}$ are shown in Fig. 3a. At room temperature, peak maxima of the $\mathrm{OH}^{-}$ modes are observed at 3606 (shoulder), 3618, 3641, 3651, and $3664 \mathrm{~cm}^{-1}$. At $80 \mathrm{~K}, \mathrm{OH}^{-}$modes are observed at 3605(?), 3612, 3622, 3639, 3649 (asymmetric band shape), 3666, and $3674 \mathrm{~cm}^{-1}$. The RT spectrum can be fit with eight bands and the spectrum recorded at $80 \mathrm{~K}$ with nine bands (Supplementary Fig. 3b and c). We do not consider the broad fitted bands occurring below $3600 \mathrm{~cm}^{-1}$, because their exact nature is uncertain. The wavenumbers of the different $\mathrm{OH}^{-}$modes in the various spectra are listed in Table 3 . Table 4 lists the amounts of $\mathrm{H}_{2} \mathrm{O}$ in the garnets, which are discussed below.

\section{Discussion}

There has been for the past 30 years the unanswerable question of why the IR spectra of various synthetic end-member silicate garnets are different from their nearly end-member natural

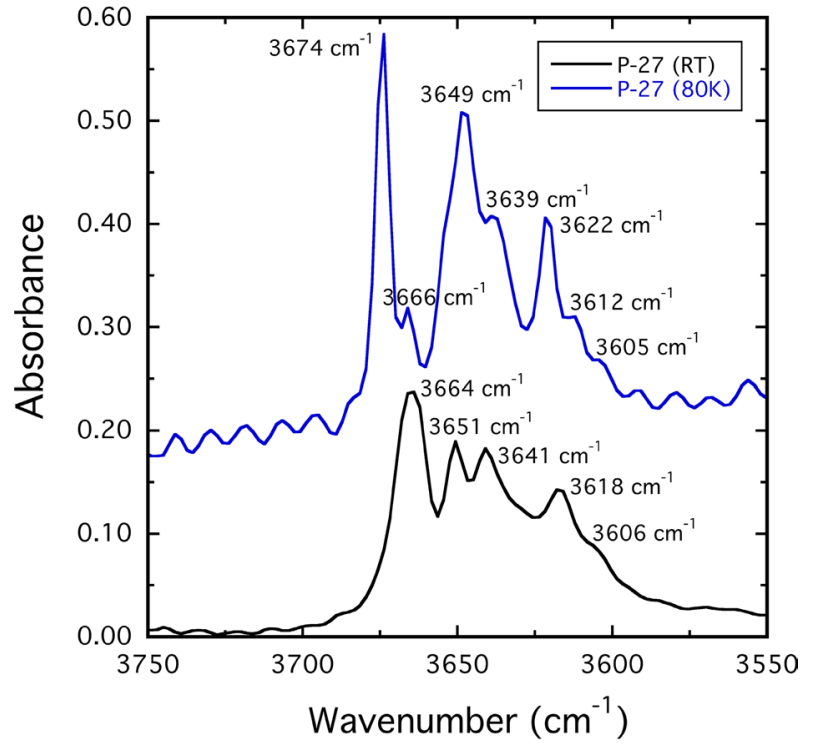

Fig. 3 a IR single-crystal spectrum at room temperature (RT) and 80 $\mathrm{K}$ of synthetic pyrope (P-27) grown hydrothermally from a gel. The crystal thickness is $0.251 \mathrm{~mm}$

analogues (see, though, Geiger and Rossman 2018, for the case of andradite and Geiger and Rossman 2020a, b, for grossular). Moreover, it was not understood why the IR spectra of DoraMaira pyropes are so different in terms of their $\mathrm{OH}^{-}$modes compared to numerous pyropes from Earth's upper mantle. Standard thinking has been that minor $\mathrm{OH}^{-}$in garnets occurs as defects, for example, $\left\{2 \mathrm{H}^{+} \Leftrightarrow \mathrm{Ca}^{2+}\right\}$ and $\left[3 \mathrm{H}^{+} \Leftrightarrow \mathrm{Al}^{3+}\right]$ in grossular (e.g., Basso et al. 1984; Birkett and Trzcienski 1984; Basso and Cabella 1990), or through coupled solid-solution mechanisms such as $\left\{\mathrm{Li}^{+}-\mathrm{H}^{+} \Leftrightarrow \mathrm{Mg}^{2+}\right\},\left[\mathrm{Mg} / \mathrm{Fe}^{2+}-\mathrm{H}^{+} \Leftrightarrow \mathrm{Al} /\right.$ $\left.\mathrm{Fe}^{3+}\right],\left(\mathrm{B}^{3+}-\mathrm{H}^{+}\right) \Leftrightarrow\left(\mathrm{Si}^{4+}\right)$ and $\left(\mathrm{Al}^{3+}-\mathrm{H}^{+}\right) \Leftrightarrow\left(\mathrm{Si}^{4+}\right)$ in various garnets (e.g., Kühberger et al 1989; Khomenko et al. 1994;

Table 1 Microprobe results expressed in oxide weight percent for the studied samples Mas-2b and Ch-2

\begin{tabular}{lrrl}
\hline Oxides & Mas-2b & Ch-2 & P-27 \\
\hline $\mathrm{SiO}_{2}$ & 44.05 & 44.79 & - \\
$\mathrm{TiO}_{2}$ & 0.01 & 0.01 & - \\
$\mathrm{Al}_{2} \mathrm{O}_{3}$ & 25.03 & 25.72 & - \\
$\mathrm{Cr}_{2} \mathrm{O}_{3}$ & 0.00 & 0.01 & - \\
$\mathrm{FeO}$ & 2.61 & 0.72 & 0.14 \\
$\mathrm{MnO}$ & 0.00 & 0.02 & - \\
$\mathrm{MgO}$ & 28.01 & 29.06 & - \\
$\mathrm{CaO}$ & 0.61 & 0.34 & 0.35 \\
$\mathrm{Total}$ & 100.32 & 100.67 & - \\
\hline Partial & results & for synthetic \\
pyrope & P-27 are based on \\
adjusted & micro-XRF measure- \\
ments & &
\end{tabular}


Table 2 Cation assignments (pfu) for various Dora-Maira pyrope samples

\begin{tabular}{lccccccc}
\hline Sample/ cations & Mas-2b & Ch-2 & GRR 945 & $\begin{array}{l}\text { GRR 1266 } \\
\text { (rim) }\end{array}$ & $\begin{array}{l}\text { GRR 1266 } \\
\text { (interior) }\end{array}$ & Mas-2a $^{\#}$ & SB-1 $^{\#}$ \\
\hline${ }^{\mathrm{IV}} \mathrm{Si}$ & 2.99 & 3.00 & 3.00 & 2.99 & 2.98 & 2.92 & 2.92 \\
${ }^{\mathrm{IV}} \mathrm{Al}$ & 0.01 & - & - & - & - & - & - \\
${ }^{\mathrm{VI}} \mathrm{Al}$ & 2.02 & 2.03 & 1.98 & 2.00 & 1.99 & 2.06 & 2.06 \\
${ }^{\mathrm{VIII}} \mathrm{Fe}^{2+}$ & 0.15 & 0.04 & 0.06 & 0.15 & 0.30 & 0.36 & 0.50 \\
${ }^{\mathrm{VIII}} \mathrm{Mg}$ & 2.79 & 2.90 & 2.94 & 2.82 & 2.62 & 2.63 & 2.47 \\
${ }^{\mathrm{VIII}} \mathrm{Ca}$ & 0.04 & 0.02 & 0.01 & 0.04 & 0.09 & 0.08 & 0.11 \\
\hline
\end{tabular}

Results from this work (left) and from the literature (right)

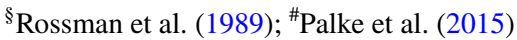

Table $3 \mathrm{OH}^{-}$mode wavenumbers $\left( \pm 1-2 \mathrm{~cm}^{-1}\right)$ determined by peak maxima and spectral fits (see supplementary Figs. 2 and 3 ) and assignments for calcium silicate garnets ${ }^{\#}$, Dora-Maira pyrope (Mas 2b) and synthetic pyrope (P-27) grown from a gel ${ }^{\S}$

\begin{tabular}{|c|c|c|c|c|c|}
\hline $\begin{array}{l}\text { Mode energy Ca } \\
\text { silicate garnet }{ }^{\#} \\
\text { (RT) }\end{array}$ & $\begin{array}{l}\text { Mode energy } \\
\text { D.M. pyrope } \\
\text { (RT) }\end{array}$ & $\begin{array}{l}\text { Mode energy D.M. pyrope } \\
(80 \mathrm{~K})\end{array}$ & $\begin{array}{l}\text { Mode energy } \\
\text { Syn. Pyrope } \\
\text { (RT) }\end{array}$ & $\begin{array}{l}\text { Mode energy Syn. } \\
\text { Pyrope }(80 \mathrm{~K})\end{array}$ & Mode assignment/ cluster type \\
\hline- & - & $3708(W)$ & - & - & $\begin{array}{l}\text { Hydrous inclusion phase - } \\
\text { phlogopite }\end{array}$ \\
\hline 3684-3688 & - & - & - & $3689(\mathrm{vW}) ?$ & $\begin{array}{l}\text { Hydrous inclusion phase - } \\
\text { lizardite }\end{array}$ \\
\hline $3674-3678$ & $3669(\mathrm{~W}) ?$ & $3676(\mathrm{M}) \& 3672(\mathrm{vW}) ?$ & - & - & $\begin{array}{l}\text { Hydrous inclusion phase- } \\
\text { antigorite (grossular) or talc } \\
\text { (pyrope)? }\end{array}$ \\
\hline$\sim 3660$ & $3660(\mathrm{~S})$ & $3666(\mathrm{~S}) / 3599(\mathrm{~W})$ & $3665(\mathrm{~S})$ & $3674(\mathrm{~S}) / 3666(\mathrm{M})$ & Finite size katoite cluster \\
\hline$\sim 3657$ & $3651(\mathrm{~S})$ & $3656(\mathrm{~S}) / 3653(\mathrm{M}) ?$ & $3651(\mathrm{M})$ & $3654(\mathrm{M})$ & $\begin{array}{l}\text { Six }\left(\mathrm{H}_{4} \mathrm{O}_{4}\right)^{4-} \text { Hydrogrossular } \\
\text { cluster }\end{array}$ \\
\hline$\sim 3641$ & 3640 (M) & 3644 (M) & $3642(\mathrm{M})$ & $3648(\mathrm{M})$ & $\begin{array}{l}\text { Five }\left(\mathrm{H}_{4} \mathrm{O}_{4}\right)^{4-} \text { Hydrogrossular } \\
\text { cluster }\end{array}$ \\
\hline$\sim 3634$ & - & - & $3630(\mathrm{M})$ & $3638(\mathrm{M})$ & $\begin{array}{l}\text { Four }\left(\mathrm{H}_{4} \mathrm{O}_{4}\right)^{4-} \text { Hydrogrossular } \\
\text { cluster }\end{array}$ \\
\hline$\sim 3622$ & $3618(W)$ & $3622(\mathrm{~W})$ & $3617(\mathrm{M})$ & $3621(\mathrm{M})$ & $\begin{array}{l}\text { Three }\left(\mathrm{H}_{4} \mathrm{O}_{4}\right)^{4-} \text { Hydrogrossular } \\
\text { cluster }\end{array}$ \\
\hline$\sim 3612$ & - & - & - & $3612(\mathrm{M})$ & $\begin{array}{l}\text { Two }\left(\mathrm{H}_{4} \mathrm{O}_{4}\right)^{4-} \text { Hydrogrossular } \\
\text { cluster }\end{array}$ \\
\hline$\sim 3599$ & $3602(\mathrm{~S})$ & $3604(\mathrm{~S})$ & $3606(\mathrm{~W})$ & $3603(\mathrm{~W})$ & $\begin{array}{l}\text { One }\left(\mathrm{H}_{4} \mathrm{O}_{4}\right)^{4-} \text { Hydrogrossular } \\
\text { cluster }\end{array}$ \\
\hline
\end{tabular}

S, strong band; M, medium strength band; W, weak band; v, very

${ }^{\#}$ Geiger and Rossman (2020a, b), ${ }^{\S}$ Geiger et al (1991)

Lu and Keppler 1997; Reynes et al. 2018). It was thought that these and other similar mechanisms "explain" the spectral differences between synthetic and natural garnets and among different natural crystals of the same species. Our spectroscopic and crystal-chemical analyses given below permit these questions and other outstanding issues and published results to be addressed in a new light. It also permits possible new insight into petrological processes using $\mathrm{OH}^{-}$in garnet. We discuss them.

\section{IR spectra of garnet, analysis of IR results on synthetic and Dora-Maira pyrope, crystal-chemical properties, and $\mathrm{H}_{\mathbf{2}} \mathrm{O}$ concentrations}

\section{State of understanding of IR spectra and $\mathrm{OH}^{-}$ in "end-member" garnet species: published results}

Synthetic "end-member" pyrope crystals synthesized hydrothermally from high-purity oxides under different $P-T-X$ conditions show a single broad (i.e., FWHH $=60 \mathrm{~cm}^{-1}$ ) asymmetric $\mathrm{OH}^{-}$band with a peak maximum at $3629 \mathrm{~cm}^{-1}$ in IR spectra at RT and two much narrower bands (both 
Table 4 Concentration of $\mathrm{H}_{2} \mathrm{O}$ in ppm by weight calculated for different pyrope samples from Dora Maira using three different garnet absorption coefficients in Rossman (2006)

\begin{tabular}{llll}
\hline Garnet sample & Pyrope & $\begin{array}{l}\mathrm{H}_{2} \mathrm{O} \text {-poor } \\
\text { grossular }\end{array}$ & $\begin{array}{l}\mathrm{H}_{2} \mathrm{O}-\text {-rich } \\
\text { grossular }\end{array}$ \\
\hline Mas-2b* $^{*}$ & 84 & 49 & 93 \\
Ch-2* & 34 & 20 & 38 \\
SB-1* & 62 & 36 & 68 \\
& 54 & 32 & 60 \\
Mas-2a* & 45 & 26 & 49 \\
GRR 1266.2 (rim) & 34 & 20 & 37 \\
GRR 1266.1 (interior) & 29 & 17 & 32 \\
& 13 & 8 & 14 \\
GRR 945 & 11 & 7 & 12 \\
\hline
\end{tabular}

In three samples, the second listed value includes a correction to the spectra to remove a band related to molecular $\mathrm{H}_{2} \mathrm{O}$ occurring in fluid inclusions

*Spectra from Geiger and Rossman (2018); ${ }^{\S}$ spectra from Rossman et al. (1989)

FWHH $=11 \mathrm{~cm}^{-1}$ ) at 3638 and $3614 \mathrm{~cm}^{-1}$ at about $80 \mathrm{~K}$ (Geiger et al. 1991). Other studies also show a single $\mathrm{OH}^{-}$ mode at about $3629 \mathrm{~cm}^{-1}$ in spectra collected at RT (Withers et al. 1998; Mookerjee and Karato 2010). Spectra measured on synthetic pyropes containing small amounts of $\mathrm{Ti}^{4+}$ and $\mathrm{V}^{4+}$ show multiple $\mathrm{OH}^{-}$bands occurring at about 3686 , 3631, 3567, and $3526 \mathrm{~cm}^{-1}$ at RT (Khomenko et al. 1994; Geiger et al. 2000). The amount of $\mathrm{OH}^{-}$in "end-member" pyrope expressed as $\mathrm{H}_{2} \mathrm{O}$ is less than about $0.1 \mathrm{wt}$. \% and has been argued, based on an analysis of IR spectra collected at RT and $80 \mathrm{~K}$ of multiple garnet species, to be held as a hydropyrope, $\mathrm{Mg}_{3} \mathrm{Al}_{2} \mathrm{H}_{12} \mathrm{O}_{12}$, component with isolated and local $\left(\mathrm{H}_{4} \mathrm{O}_{4}\right)^{4-}$ groups in an "anhydrous matrix" (Geiger and Rossman 2018).

The IR spectra of pyropes with an 83 to $98 \mathrm{~mol} \%$ $\mathrm{Mg}_{3} \mathrm{Al}_{2} \mathrm{Si}_{3} \mathrm{O}_{12}$ component from Dora-Maira (Rossman et al. 1989; Lu and Keppler 1997; Guastoni et al. 2001; Blanchard and Ingrin 2004a, b; Geiger and Rossman 2018) are completely different in appearance from all the above synthetic pyropes. It was initially thought that the $\mathrm{OH}^{-}$incorporation mechanism in most pyrope-rich crystals could be similar to that of the "end-member" synthetics, but this was shown not to be the case. The pyropes from Dora-Maira also have less $\mathrm{H}_{2} \mathrm{O}$, calculated as 0.002-0.003 wt. \% (Rossman et al. 1989), 13 to $36 \mathrm{ppm}$ (Blanchard and Ingrin 1994a, b) and 58 ppm by weight (Lu and Keppler 1997), than the synthetics.

The IR spectra of $\mathrm{OH}^{-}$-bearing and natural nearly "endmember" grossular and andradite, ideal anhydrous endmember formulae $\mathrm{Ca}_{3} \mathrm{Al}_{2} \mathrm{Si}_{3} \mathrm{O}_{12}$ and $\mathrm{Ca}_{3} \mathrm{Fe}^{3+}{ }_{2} \mathrm{Si}_{3} \mathrm{O}_{12}$, respectively, are, in general, more variable and complex (Rossman and Aines 1991; Maldener et al. 2003; Phichaikamjornwut et al. 2011; Dachs et al. 2012; Reynes et al. 2018) than those of Dora-Maira pyrope. $\mathrm{OH}^{-}$stretching modes of a number of different energies are observable in the former. Geiger and Rossman (2020a, b) analyzed the available spectra and introduced an atomic vibrational and a crystal-chemical model to assign most of the observed $\mathrm{OH}^{-}$modes, which were previously not assignable and whose physical origin was not understood. They argued that various local, microscopic and barely nano-scale hydrogarnet (hydrogrossular and hydroandradite)-like clusters could be distributed throughout an anhydrous calcium-silicate-garnet "host matrix". The basic substitution mechanism is the hydrogarnet one, where $\left(\mathrm{H}_{4} \mathrm{O}_{4}\right)^{4-} \Leftrightarrow\left(\mathrm{SiO}_{4}\right)^{4-}$, and various local configurations containing different numbers of $\left(\mathrm{H}_{4} \mathrm{O}_{4}\right)^{4-}$ groups define the cluster type. The $\mathrm{OH}^{-}$modes associated with different hydrogrossular-like $\left(\mathrm{Ca}_{3} \mathrm{Al}_{2} \mathrm{H}_{12} \mathrm{O}_{12}\right)$ groups (one $\left(\mathrm{H}_{4} \mathrm{O}_{4}\right)^{4-}$ unit) or clusters (more than one $\left(\mathrm{H}_{4} \mathrm{O}_{4}\right)^{4-}$ group) have energies of about $3599,3612,3622,3633,3641$ and $3657 \mathrm{~cm}^{-1}$ at RT, being fairly regularly spaced in wavenumber (Table 3). A further $\mathrm{OH}^{-}$mode at about $3660 \mathrm{~cm}^{-1}$ reflects the presence of $\mathrm{OH}^{-}$in more extended, yet finitesized katoite $\left(\mathrm{Ca}_{3} \mathrm{Al}_{2} \mathrm{H}_{12} \mathrm{O}_{12}\right)$-like clusters or larger domains. The presence or absence of the various modes can vary from grossular to grossular sample, as can the mode intensities.

\section{Dora-Maira pyrope: IR spectra, $\mathrm{OH}^{-}$band assignments, and hydrogrossular-like clusters}

The IR spectra of Dora-Maira pyrope crystals show five $\mathrm{OH}^{-}$bands at $3602,3618,3641,3651$, and $3660 \mathrm{~cm}^{-1}$ at RT (Fig. 2a). We think that the general similarity in wavenumber of these $\mathrm{OH}^{-}$modes with those observed in grossular (Table 3) is no coincidence (Note, though, that an equivalent $\mathrm{OH}^{-}$mode at about $3633 \mathrm{~cm}^{-1}$ is absent in Dora-Maira pyrope. A mode at $3651 \mathrm{~cm}^{-1}$ is also present, whereas its possible equivalent is located at about $3657 \mathrm{~cm}^{-1}$ in grossular). It should also be stated that the IR spectra of many spessartine garnets show " $\mathrm{OH}^{-}$mode patterns" broadly similar to those of pyrope from Dora-Maira (Geiger and Rossman 2018; Geiger and Rossman unpub.).

Thus, we think that $\mathrm{OH}^{-}$in Dora-Maira garnets is also contained in different micro- and barely nano-size hydrogrossular-like clusters. In fact, $\mathrm{OH}^{-}$partitioning into these clusters in the pyrope appears quantitative. We find no evidence for any "hydropyrope-like" $\left(\mathrm{H}_{4} \mathrm{O}_{4}\right)^{4-}$ groups, as proposed for synthetic pyrope. The assignments of the different energy $\mathrm{OH}^{-}$modes for both grossular and Dora-Maira pyrope are listed in Table 3 and the associated clusters are shown in Fig. 4 (see also Geiger and Rossman 2020a). A key point in this analysis is that the $\mathrm{OH}^{-}$stretching vibration can couple or is affected by other cation-related vibrations that share the same common oxygen atom (the atomic vibrational "fragment" shown in Fig. 2 of Geiger and Rossman 2020a). Furthermore, it is also possible, that more extended mode 
Fig. 4 Various hypothetical hydrogrossular-like clusters in pyrope. $\mathrm{H}$ atoms are pink, $\mathrm{SiO}_{4}$ groups are red and $\mathrm{AlO}_{6}$ groups are blue. Hydrogarnet $\left(\mathrm{H}_{4} \mathrm{O}_{4}\right)^{4-}$

"tetrahedra" are shown in green. The oxygen atoms located at the corners of the polyhedra and $\mathrm{X}$-cations are not shown for the sake of clarity. a Crystalchemical environment for endmember katoite or a finite-sized katoite-like cluster or domain, as given by the $\mathrm{RT} \mathrm{OH}^{-}$stretching mode at 3660-3665 $\mathrm{cm}^{-1}$. b A single $\left(\mathrm{H}_{4} \mathrm{O}_{4}\right)^{4-}$ group as given by an $\mathrm{OH}^{-}$stretching mode at about $3602-3606 \mathrm{~cm}^{-1}$. c Cluster arrangement involving two $\left(\mathrm{H}_{4} \mathrm{O}_{4}\right)^{4-}$ groups and the rest $\mathrm{SiO}_{4}$ groups, as given by an $\mathrm{OH}^{-}$mode at about $3611 \mathrm{~cm}^{-1}$. d Cluster arrangement involving three $\left(\mathrm{H}_{4} \mathrm{O}_{4}\right)^{4-}$ groups and the rest $\mathrm{SiO}_{4}$ groups, as given by an $\mathrm{OH}^{-}$mode at about $3618 \mathrm{~cm}^{-1}$. e Cluster arrangement involving four $\left(\mathrm{H}_{4} \mathrm{O}_{4}\right)^{4-}$ groups and the rest $\mathrm{SiO}_{4}$ groups, as given by an $\mathrm{OH}^{-}$mode at about $3630 \mathrm{~cm}^{-1}$, f cluster arrangement involving five $\left(\mathrm{H}_{4} \mathrm{O}_{4}\right)^{4-}$ groups and a single $\mathrm{SiO}_{4}$ group, as given by an $\mathrm{OH}^{-}$mode at about 3640-3642 $\mathrm{cm}^{-1}$ and $\mathbf{g}$ cluster arrangement involving six $\left(\mathrm{H}_{4} \mathrm{O}_{4}\right)^{4-}$ groups given by an $\mathrm{OH}^{-}$mode at about $3651-3657 \mathrm{~cm}^{-1}$
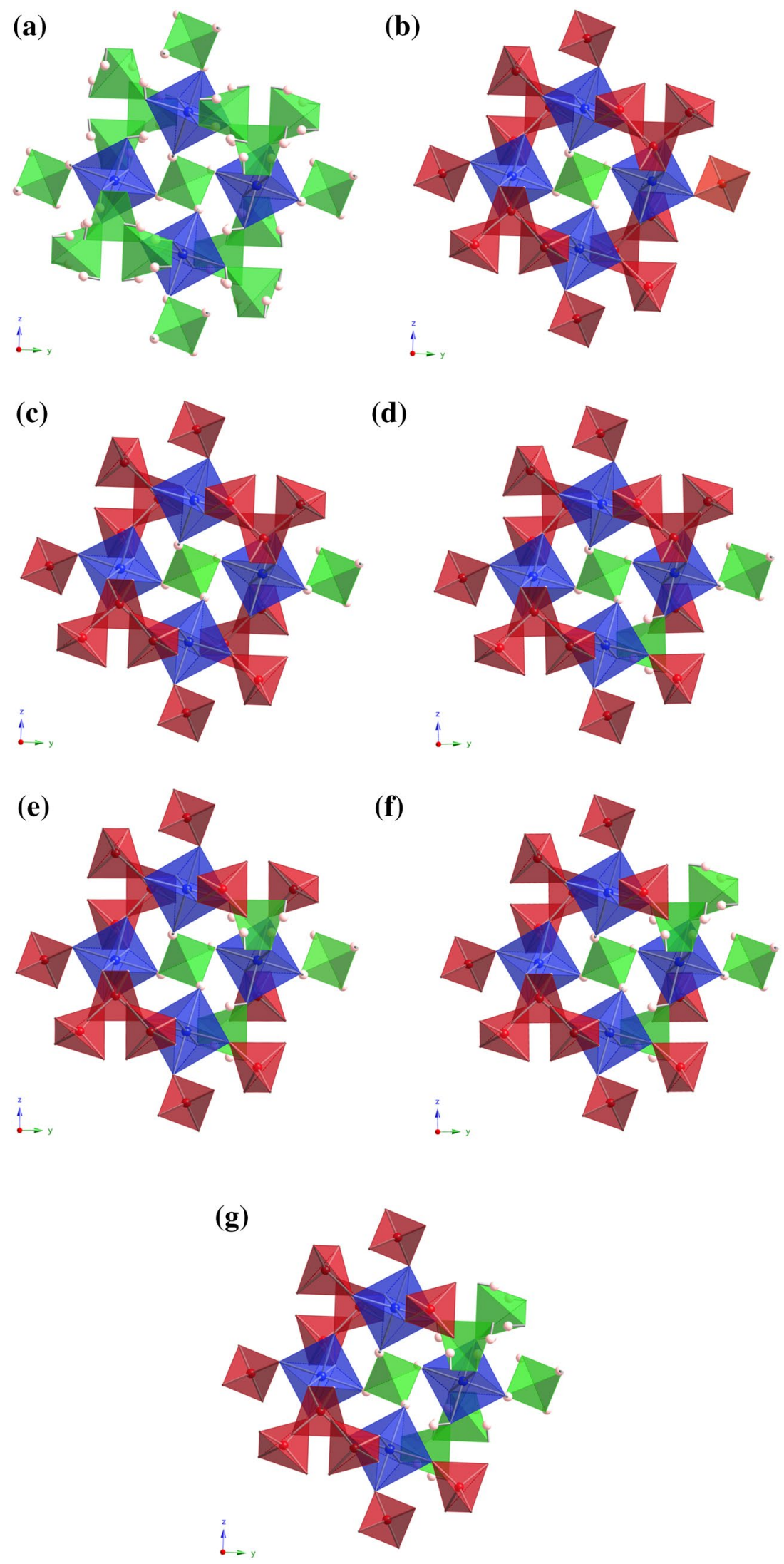
coupling can occur in as much as crystals have lattice vibrations and not isolated modes. These effects give rise to the different energies, either large or small, in $\mathrm{OH}^{-}$stretching wavenumbers among the various garnet species.

The spectrum of pyrope Mas- $2 \mathrm{~b}$ recorded at $80 \mathrm{~K}$ reveals more information. At least nine bands can be fit to the spectrum (Supplementary Fig. 2c). We think those at 3604, 3622,3644 , and $3653 / 3656 \mathrm{~cm}^{-1}$ are related to various hydrogrossular-like clusters (Table 3 ). The mode at 3666 $\mathrm{cm}^{-1}$ is related to larger katoite-like clusters or domains and the weak mode at $3599 \mathrm{~cm}^{-1}$ may arise at low temperatures, as described by Kolesov and Geiger (2005) in the spectra of a synthetic end-member katoite. The precise nature of the two closely spaced bands at 3653 and $3656 \mathrm{~cm}^{-1}$ at $80 \mathrm{~K}$ is not fully clear to us (see discussion below).

The weak high-wavenumber $\mathrm{OH}^{-}$modes above about $3666 \mathrm{~cm}^{-1}$ can have other origins. The band at $3676 \mathrm{~cm}^{-1}$ can be assigned to the possible presence of tiny talc inclusions (see the case for talc in andradite in Geiger et al. 2018). The mode at $3708 \mathrm{~cm}^{-1}$ is also possibly related to a layer silicate and, here, phlogopite may come into play (Farmer and Russell 1967; Beran 2002). Spectral fine structure can be complicated, because pyrope crystals at Dora-Maira are chock-full of various solid-inclusion phases (e.g., Simon and Chopin 2001; Ferrando et al. 2009; Schertl et al. 2018) including Mg-rich phlogopite and talc. They may be present as minute crystals not observable using standard microscope techniques.

\section{Synthetic pyrope grown from a gel: IR spectra, $\mathrm{OH}^{-}$band assignments, and hydrogrossular-like clusters}

Geiger et al. (1991) investigated the nature of $\mathrm{OH}^{-}$incorporation in a large number of synthetic pyropes grown with different starting materials under different $P, T$ and fluidcomposition conditions. They noted that the IR spectra of pyropes synthesized from a gel were fundamentally different in appearance (Fig. 3a) from those grown from high purity oxides. A spectrum of the former type (i.e., sample P-27) could not be interpreted at that time.

From the RT IR spectrum of sample-P-27, $\mathrm{OH}^{-}$modes can be fit at 3565, 3597, 3606, 3617, 3630, 3642, 3651 and $3665 \mathrm{~cm}^{-1}$ (Supplementary Fig. 3b). For the $80 \mathrm{~K}$ spectrum, $\mathrm{OH}^{-}$modes can be fit at 3603, 3612, 3621, 3638, 3648, 3654, 3666, 3674 and $3686 \mathrm{~cm}^{-1}$ (Supplementary Fig. 3c). This synthetic pyrope crystal contains small amounts of $\mathrm{Ca}$ (Table 2). Apparently, the gel-starting material used for the synthesis experiments contained small concentrations of $\mathrm{Ca}$ and $\mathrm{Fe}$ "impurities". From this, we think that the $\mathrm{OH}^{-}$ is also probably partitioned into hydrogrossular-like clusters (Table 3). This is notable, because this is the first case where $\mathrm{OH}^{-}$incorporation mechanisms are similar—but not

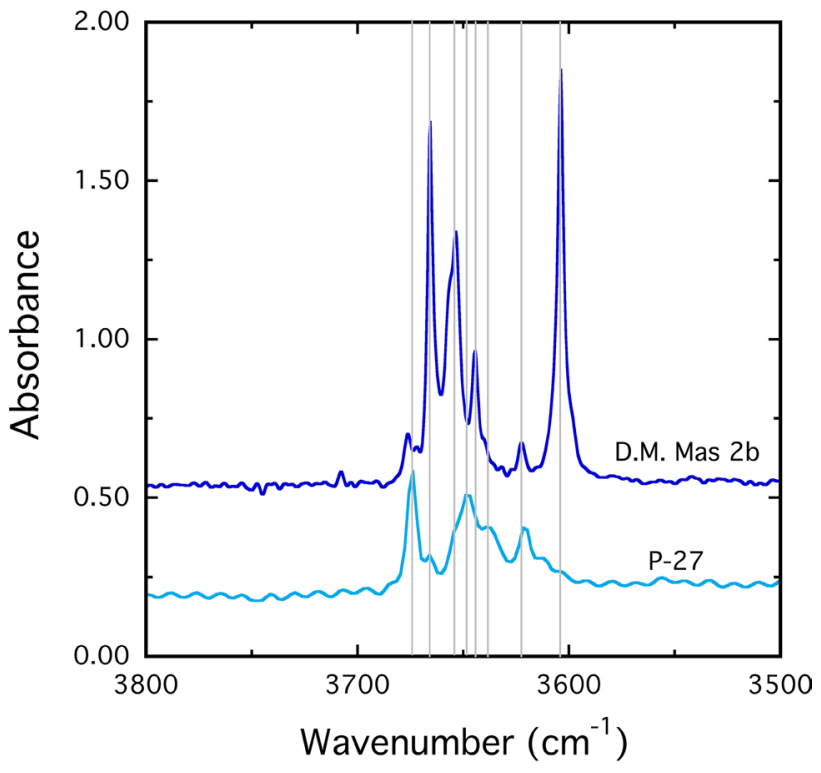

Fig. 5 Comparison of IR spectra at $80 \mathrm{~K}$ between synthetic pyrope grown from a gel and natural pyrope from Dora Maira. The thin vertical gray lines are drawn through various peak maxima of the different $\mathrm{OH}^{-}$modes

exactly the same-between a natural and synthetic garnet solid solution.

A comparison of the spectra at $80 \mathrm{~K}$ of synthetic pyrope P-27 and Dora-Maira garnet MAS-2b is shown in Fig. 5. There is a match in energy for most of the $\mathrm{OH}^{-}$modes, but the intensities can be different. The lowest wavenumber mode in the spectrum of the natural pyrope is intense, while it is weak in the spectrum of the synthetic. We have presently no explanation for this. We can only state that mode intensity depends on the nature of the dipole interaction and this can be expected to be complex, especially if mode coupling and mixing come into play.

\section{Local crystal-chemical properties and $\left(\mathrm{H}_{4} \mathrm{O}_{4}\right)^{4-}$ groups and clusters}

If hydrogrossular-like clusters are present in pyrope crystals, then this has key crystal-chemical implications. Both local structural and compositional heterogeneities can exist in garnet because of short-range $\mathrm{Ca}$ and proton ordering. Slight short-range $\mathrm{Ca}$ and $\mathrm{Mg}$ cation ordering has been proposed to occur in synthetic anhydrous pyrope-grossular garnets based on ${ }^{29}$ Si MAS NMR experiments and empirical pairpotential calculations (Bosenick et al. 1995, 1999, 2000), but it has not yet been determined for any rock-forming, natural silicate garnet (see Palke et al. 2015), as best as we know. The latter workers did investigate pyropes from Dora-Maira, using paramagnetically shifted ${ }^{27} \mathrm{Al}$ and ${ }^{29} \mathrm{Si}$ MAS NMR resonances, but they did not document any cation ordering. 
The dimensions of the clusters, based on the placement of the $\left(\mathrm{H}_{4} \mathrm{O}_{4}\right)^{4-}$ groups, cannot be determined from the IR spectra, but they can be estimated. The atomic crystal structures of end-member pyrope, grossular, and katoite are known (Armbruster et al. 1992; Geiger and Armbruster 1997; Lager et al. 1987). The distance across a single $\left(\mathrm{H}_{4} \mathrm{O}_{4}\right)^{4-}$ group is roughly $3 \AA$ (Fig. 4b). A hydrogrossular-like cluster of the type shown in Fig. 4g should be a little less than $10 \AA$ in dimension, as measured from outer opposing $\left(\mathrm{H}_{4} \mathrm{O}_{4}\right)^{4-}$ to $\left(\mathrm{H}_{4} \mathrm{O}_{4}\right)^{4-}$ group. A more extended, yet finite size, katoitelike-cluster or domain should have a minimum dimension of roughly $15 \AA$ (Fig. 4a). Its exact upper size limit is not known.

A given cluster type is characterized by the number of $\left(\mathrm{H}_{4} \mathrm{O}_{4}\right)^{4-}$ groups, but they can have different local arrangements (see Geiger and Rossman 2020a, b). It can be expected that the nature of local structural relaxation will be different depending on the cluster type and precise $\left(\mathrm{H}_{4} \mathrm{O}_{4}\right)^{4-}$ group arrangements for each cluster type. This could give rise to slight variations in $\mathrm{OH}^{-}$mode energies and intensities, as observed between the spectra of Dora-Maira and synthetic pyrope (i.e., P-27).

\section{Determination of $\mathrm{H}_{2} \mathrm{O}$ content in Dora-Maira pyrope: consequences of the cluster model}

The fact that the various hydrogrossular-like clusters have different $\mathrm{OH}^{-}$-mode energies indicates that the molar IR absorption coefficients associated with each type could have different values (Libowitzky and Rossman 1997). How different they could be remains to be determined. The analysis, herein, and in Geiger and Rossman (2020a, b), sets out how absorption coefficient determinations for $\mathrm{H}_{2} \mathrm{O}$ in garnet should be undertaken and what spectral aspects need to be considered.

We calculated the $\mathrm{H}_{2} \mathrm{O}$ concentrations for the pyropes Mas-2b and Ch-2 (Table 2), as well as SB-1 (locality San Bernardo) and Mas-2a (locality Masueria), discussed in Geiger and Rossman (2018) and Palke et al. (2015), and the Dora-Maira garnets GRR 1266.1, GRR 1266.2 and GRR 945 described in Rossman et al. (1989). Three different absorption coefficients were used, namely those for pyrope, $\mathrm{H}_{2} \mathrm{O}$-poor grossular and $\mathrm{H}_{2} \mathrm{O}$-rich grossular ("hydrogrossular"), as given in Rossman (2006). Results are listed in Table 4. All three coefficients were used to illustrate the differences in the amounts of $\mathrm{H}_{2} \mathrm{O}$ obtained. Based on the analysis and arguments made herein, the absorption coefficient for $\mathrm{H}_{2} \mathrm{O}$-poor grossular should give the best measure of $\mathrm{H}_{2} \mathrm{O}$ concentrations and not that for pyrope.

Consider, further, the issue regarding the use of the proper absorption coefficients for $\mathrm{H}_{2} \mathrm{O}$ and even for the same garnet species. There is a significant difference in the absorbance coefficients between $\mathrm{H}_{2} \mathrm{O}$-rich and $\mathrm{H}_{2} \mathrm{O}$-poor grossular. They are different by about a factor of two and at first thought this may seem illogical considering that both are for grossular garnet (see Fig. 1 of Geiger and Rossman 2020a). However, an analysis of their respective IR spectra and their crystalchemical properties can possibly explain the difference. The IR spectra of katoite (end-member formula $\left.\mathrm{Ca}_{3} \mathrm{Al}_{2}\left(\mathrm{H}_{4} \mathrm{O}_{4}\right)_{3}\right)$ and $\mathrm{H}_{2} \mathrm{O}$-rich grossular are characterized by broad $\mathrm{OH}^{-}$ stretching bands (for GRR 1059, the $3662 \mathrm{~cm}^{-1}$ band is $\sim 30$ $\mathrm{cm}^{-1} \mathrm{FWHH}$; for GRR 1329, the $3668 \mathrm{~cm}^{-1}$ band is $\sim 32$ $\mathrm{cm}^{-1} \mathrm{FWHH}$ and the $3596 \mathrm{~cm}^{-1}$ band is $\sim 65 \mathrm{~cm}^{-1} \mathrm{FWHH}$ ), whereas these bands in the spectra of $\mathrm{H}_{2} \mathrm{O}$-poor grossular are much narrower (see Geiger and Rossman 2020a). The nature of IR mode broadening in garnet was discussed in that study. We think that the large vibrational amplitudes associated with the light hydrogen atoms in "expanded garnet structures" such as katoite or in extended katoite-like domains in katoite-grossular solid solutions, compared to the case for $\mathrm{H}_{2} \mathrm{O}$-poor grossular, are the cause for the broader $\mathrm{OH}^{-}$modes in the spectra of the former. In other words, the vibrational behavior of hydrogen atoms in hydrogrossular-like clusters in nearly end-member grossular will be controlled by the smaller volume anhydrous grossular host structure. Narrower $\mathrm{OH}^{-}$stretching modes result. We think that the nature of local structural relaxation is important in controlling the vibrational behavior of hydrogen atoms. It follows that the areas associated with the respective $\mathrm{OH}^{-}$bands will be different, as will the absorption coefficients.

Returning back to the spectra of Dora-Maira pyrope, the narrow $\mathrm{OH}^{-}$stretching modes of these garnets are most similar in terms of vibrational behavior (i.e., both energy and band widths) to those in $\mathrm{H}_{2} \mathrm{O}$-poor grossular.

\section{There are pyropes and there are pyropes: differences in composition, origin, and $\mathrm{OH}^{-}$incorporation mechanisms}

Mantle pyropes display completely different IR spectra than pyropes at Dora-Maira. The former are often characterized, for example, by a prominent $\mathrm{OH}^{-}$mode at $3570 \mathrm{~cm}^{-1}$ (Bell and Rossman 1992b). It goes without out saying that pyropes from Earth's mantle, as found in various xenoliths from kimberlites (e.g., Bell and Rossman 1992b; Matsyuk et al. 1998), and in other types of eclogites (e.g., Schmädike et al. 2015; Liu et al. 2016; Gose and Schmädicke 2018; Zhang et al. 2019) and pyroxenites (Li et al. 2018), have a completely different petrologic origin than those found in the UHP whiteschists and quartzites at Dora Maira. The chemistries of mantle garnets are more complex and varied, as they contain a number of chemical components (Dawson and Stephens 1975).

Bell and Rossman (1992b) wrote "OH abundances in garnet are closely linked to host rock paragenesis and cannot be explained purely by any crystal chemical factors which we have investigated". The results of this study indicate that 
crystal-chemical factors can play a role in the incorporation of $\mathrm{OH}^{-}$in pyrope. Dora-Maira pyropes show a distinctive IR "signature" reflecting $\mathrm{OH}^{-}$incorporation mechanisms similar to that found in crustal grossulars, andradite (Geiger and Rossman 2020a, b) and many spessartines (Geiger and Rossman unpub.). In light of this observation, we discuss briefly the petrologic history at Dora-Maira.

\section{Petrology of the UHP rocks at Dora-Maira and the role of pyrope}

Investigations of the metamorphic conditions of the different garnet-bearing lithologies of the UHP Dora-Maira Massif have been undertaken (e.g., Simon et al. 1997; Chopin and Schertl 1999; Ferrando et al. 2009; Groppo et al. 2019). The crystallization of pyrope within the Brossasco-Isasca Unit is complex, involving different stages during the $P-T-t$ cycle. Pyropes of different types (i.e., megablasts, porphyroblasts and neoblasts) and generations have different compositions, and zoning within some crystal types can be observed.

Ferrando et al. (2009) discuss, in detail, the complex metamorphic evolution consisting of five stages from A to E, and we summarize their findings. Three generations of pyrope growth (stages $\mathrm{C}, \mathrm{D}$ and $\mathrm{E}$ ) can be recognized by their forms, compositions and mineral inclusions. The first generation (i.e., their Pyp I: $\mathrm{Pyr}_{69-81} \mathrm{Almd}_{16-26}$ ) was considered prograde and it contains inclusions of kyanite, talc, phlogopite (regressed to vermiculite), $\mathrm{Mg}$-chlorite and other phases. We note that the IR spectrum of pyrope Mas- $2 b$ may possibly record very minor minute inclusions of talc and phlogophite (Fig. 2). The $P-T$ conditions for stage $\mathrm{C}$ were estimated to be $2.1<P<2.8 \mathrm{GPa}$ and $590<T<650{ }^{\circ} \mathrm{C}$. A second generation of pyrope (Pyp II: Pyr $_{82-98} A_{1 m d_{1-16}}$ ) crystallized at peak metamorphic conditions (stage $\mathrm{D}$ ) and it contains only rarely talc but never $\mathrm{Mg}$-chlorite and phlogopite. $P-T$ conditions were $T \sim 730{ }^{\circ} \mathrm{C}$ and $P \sim 4.0$ to $4.3 \mathrm{GPa}$. A third generation of pyrope (Pyp III: $\mathrm{Pyr}_{86-67} \mathrm{Almd}_{4-11}$ ) is considered to be retrograde (stage $\mathrm{E}$ ) and it is usually replaced by phengite, biotite, talc, kyanite, and chlorite. Here, Ferrando et al. (2009) give $T \sim 720{ }^{\circ} \mathrm{C}$ and $P \sim 3.6-3.9 \mathrm{GPa}$.

Sharp et al. (1999) argued that the water activity, $a_{\mathrm{H} 2 \mathrm{O}}$, during metamorphism must have been lower than 1.0, lying between 0.4 and 0.75 at $700-750{ }^{\circ} \mathrm{C}$. Ferrando et al. (2009) describe two generations of fluid inclusions (i.e., type-I and type-II) with type-I forming during prograde metamorphism. The fluid was complex in composition being termed a $\mathrm{NaCl}-\mathrm{MgCl}_{2}$-bearing brine with 6 to $28 \mathrm{NaCl}_{\text {eq }}$ (in wt. \%). At peak metamorphic conditions (stage D), the fluid was different in nature, here, being described as "an aluminosilicate aqueous solution with a composition intermediate between an aqueous fluid and a silicate melt".

We note that the IR spectra of all pyrope samples from Dora-Maira that have been studied to date, regardless of their composition and locality, are similar in terms of the number and energies of the $\mathrm{OH}^{-}$bands (Rossman et al. 1989; Lu and Keppler 1997; Guastoni et al. 2001; Blanchard and Ingrin 2004a, b; Geiger and Rossman 2018; this work). The mechanism of $\mathrm{OH}^{-}$incorporation in all crystals appears to be similar. The spectra do not indicate the presence of any hydropyrope-like substitution only a hydrogrossular-like one. The phase relations of the grossular-katoite ("hydrogrossularite") system have been studied to $P_{\mathrm{H} 2 \mathrm{O}}=15.5 \mathrm{kbar}$ and to $850{ }^{\circ} \mathrm{C}$ (Pistorius and Kennedy 1960). They allow a possible, simple interpretation of the behavior of hydrogrossular-like clusters in pyrope. Their results show that the amount of $\mathrm{H}_{2} \mathrm{O}$ in garnet (i.e., "hydrogrossular") is mostly a function of temperature. Above about $800{ }^{\circ} \mathrm{C}$, garnet is "anhydrous". Though not investigated by Pistorius and Kennedy (1960), a lowering of $a_{\mathrm{H} 2 \mathrm{O}}$ below 1.0 should also act to decrease the amount of $\mathrm{H}_{2} \mathrm{O}$ in garnet. We think both factors could possibly explain the low-water contents (Table 4) in the pyropes at Dora-Maira. In other words, low temperatures and high $a_{\mathrm{H} 2 \mathrm{O}}$ act to stabilize the hydrogrossular component. It follows that the precise type of the hydrogrossular-like cluster, and its concentrations in pyrope, could reveal information about the $P-T-X$ crystallization conditions assuming chemical equilibrium prevailed.

Based on the compositions of our different pyropes (Table 2b), we can consider that samples SB-1 and possibly Mas-2a and GRR 1266 (interior) represent "Pyp-I" garnets that crystallized at metamorphic stage $\mathrm{C}$. The more pyroperich samples Ch-2, Mas-2b and GRR 945 possibly represent peak metamorphic "Pyp-II" crystals. We analyzed the concentrations of $\mathrm{H}_{2} \mathrm{O}$ (Table 4) for the different pyrope samples as a function of their atomic $\mathrm{Ca}$ and $\mathrm{Fe}^{2+}$ contents using the data in Table 2. We could not discern any clear relationship. It appears that the amounts of $\mathrm{CaO}$ and $\mathrm{Al}_{2} \mathrm{O}_{3}$ in the pyrope crystals should be more than enough to account for all the structural $\mathrm{OH}^{-}$in hydrogrossular-like clusters (a calculation of various anhydrous garnet components, using the formulation of Locock 2008, gives $1.4 \mathrm{~mol} \%$ grossular for sample Mas-2b and $0.8 \mathrm{~mol} \%$ for sample Ch-2). Finally, Fig. 6 shows the concentration of $\mathrm{H}_{2} \mathrm{O}$ for possible Pyp-I and Pyp-II samples. There might be a tendency for the latter peak-metamorphic garnets to have on average more $\mathrm{H}_{2} \mathrm{O}$.

Additionally, pyrope GRR 1229 (Table 4) has roughly twice as much $\mathrm{H}_{2} \mathrm{O}$ at its rim as it does at its core. At the simplest level, one could suggest, because the temperature of metamorphic stage $\mathrm{D}$ was greater than that of stage $\mathrm{C}$, that $a_{\mathrm{H} 2 \mathrm{O}}$ may have been the deciding factor and it could have been higher at peak metamorphic conditions. This analysis is preliminary and elementary, and research needs to be done in this direction to explain the $\mathrm{H}_{2} \mathrm{O}$ amounts and their distribution in garnet crystals at Dora-Maira.

Finally, we note, to end this section, that Geiger et al. (1991) synthesized pyrope from high purity oxides, at high 


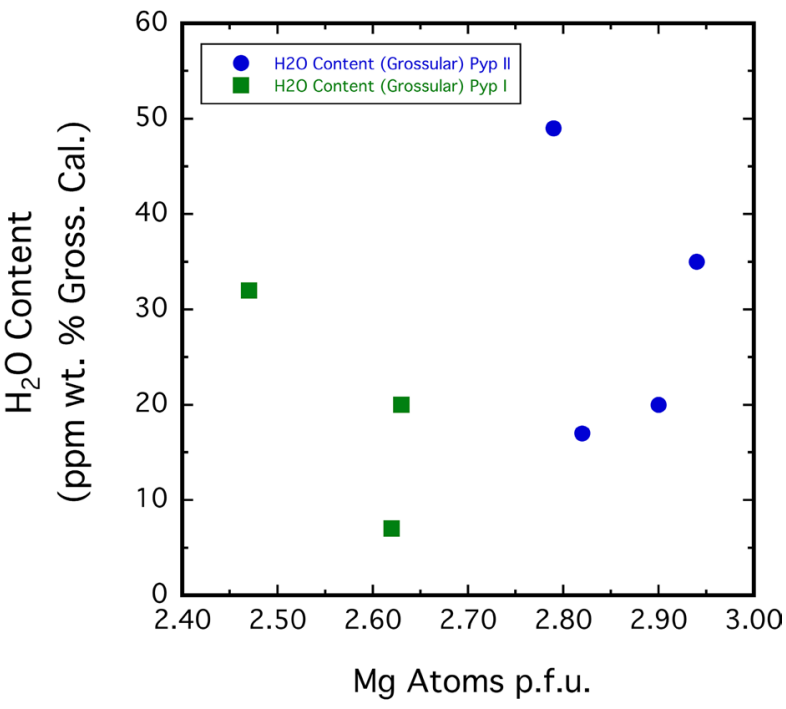

Fig. $6 \mathrm{H}_{2} \mathrm{O}$ content, adopting the absorption coefficient for $\mathrm{H}_{2} \mathrm{O}$-poor grossular (Table 4), in different pyrope crystals from Dora Maira as a function of the number of $\mathrm{Mg}$ cations in the formula unit. The more pyrope-rich samples (Pyp II-see text and Ferrando et al. 2009) could have crystallized during peak metamorphism, whereas the more pyrope-poor samples (Pyp I) during prograde metamorphic conditions (see text)

$P$ and $T$ in $\mathrm{H}_{2} \mathrm{O}$ solutions containing $\mathrm{NaOH}$ and $\mathrm{HCl}$ (basic and acidic conditions, respectively). The IR spectra of these garnets were, though, the same as those crystals grown in pure $\mathrm{H}_{2} \mathrm{O}$. That is, they show a broad asymmetric $\mathrm{OH}^{-}$band at RT with a peak maximum at $3629 \mathrm{~cm}^{-1}$. This would seem to indicate that fluid brines, alone, operating during metamorphism of the Dora-Maira rocks, are probably not the cause for the unusual $\mathrm{OH}^{-}$incorporation mechanism in the pyrope crystals.

\section{Reinterpretation of published results relating to $\mathrm{OH}^{-}$ in Dora-Maira pyrope}

\section{Hydration behavior of Dora-Maira pyrope at high $P_{\mathrm{H} 2 \mathrm{O}}$ and $T$}

Our cluster model allows the experimental results of $\mathrm{Lu}$ and Keppler (1997) on the incorporation and behavior of $\mathrm{OH}^{-}$in Dora-Maria pyrope at high $P_{\mathrm{H} 2 \mathrm{O}}$ and $T$ to be interpreted in a new light. Their sample chosen for study had the anhydrous crystal-chemical formula $\left\{\mathrm{Mg}_{2.74}, \mathrm{Fe}^{2+}{ }_{0.16}\right.$, $\left.\mathrm{Ca}_{0.04}\right\}_{2.94}\left[\mathrm{Al}_{1.99}, \mathrm{Ti}_{0.02}, \mathrm{Si}_{0.04}\right]_{2.05} \mathrm{Si}_{3.00} \mathrm{O}_{12}$, calculated using their analytical data and following Locock (2008). It also contained minor $\mathrm{Cr}_{2} \mathrm{O}_{3}, \mathrm{~B}_{2} \mathrm{O}_{3}, \mathrm{MnO}, \mathrm{Li}_{2} \mathrm{O}, \mathrm{Na}_{2} \mathrm{O}$ and $\mathrm{K}_{2} \mathrm{O}$ and they proposed that the coupled-substitution mechanisms ${ }^{\mathrm{VIII}} \mathrm{Li}^{+}-\mathrm{H}^{+} \Leftrightarrow{ }^{\mathrm{VIII}} \mathrm{Mg}^{2+}$ or ${ }^{\mathrm{IV}} \mathrm{B}^{3+}-\mathrm{H}^{+} \Leftrightarrow{ }^{\mathrm{IV}} \mathrm{Si}^{4+}$ could explain $\mathrm{OH}^{-}$incorporation in the garnet.

To study the nature of $\mathrm{H}_{2} \mathrm{O}$ incorporation, they treated their crystal to varying high $P_{\mathrm{H} 2 \mathrm{O}}$ and $T$ conditions in the laboratory. In short, they observed in the IR spectra of the pyrope single crystals, following treatment, that the $\mathrm{OH}^{-}$ modes at 3641,3651 and $3661 \mathrm{~cm}^{-1}$ increased in intensity, while that at $3602 \mathrm{~cm}^{-1}$ decreased. We think that these results indicate that more $\mathrm{H}_{2} \mathrm{O}$-rich clusters, like the types shown in Fig. 4a, f and g, increase in number. In a simple and general sense, a local-cluster hydration reaction could be given, for example, by

$\mathrm{Ca}_{3} \mathrm{Al}_{2}\left(\mathrm{H}_{2.0} \mathrm{Si}_{2.5}\right) \mathrm{O}_{12}+3 \mathrm{H}_{2} \mathrm{O} \rightarrow \mathrm{Ca}_{3} \mathrm{Al}_{2}\left(\mathrm{H}_{8.0} \mathrm{Si}_{1.0}\right) \mathrm{O}_{12}+1.5 \mathrm{SiO}_{2}$.

This reaction is based on the assumption of a 12 oxygen formula unit and it requires that $\mathrm{SiO}_{2}$ be precipitated locally. This proposal could be tested experimentally. It is of note that (1) would require the breaking and reforming of strong $\mathrm{Si}-\mathrm{O}$ bonds, but the hydrothermal experiments were made at 800 to $1200{ }^{\circ} \mathrm{C}$ (Lu and Keppler 1997).

The cluster model explains, furthermore, why $\mathrm{H}_{2} \mathrm{O}$ incorporation is not noticeably dependent on $f_{\mathrm{O} 2}$ (the hydrothermal experiments were done under $f_{\mathrm{O} 2}$ conditions defined by the $\mathrm{Fe}-\mathrm{FeO}$ and $\mathrm{Ni}-\mathrm{NiO}$ buffers). The crystal-chemical nature of the different cluster types also explains why the $\mathrm{OH}^{-}$stretching mode at $3602 \mathrm{~cm}^{-1}$ is "stiffer in behavior", as based on IR measurements made on the pyrope crystal in a diamond-anvil cell (Lu and Keppler 1997), compared to the higher energy $\mathrm{OH}^{-}$modes at 3641,3651 and $3661 \mathrm{~cm}^{-1}$. The latter represent larger clusters having greater numbers of $\left(\mathrm{H}_{4} \mathrm{O}_{4}\right)^{4-}$ groups. Indeed, the structure of $\mathrm{Ca}_{3} \mathrm{Al}_{2}\left(\mathrm{H}_{4} \mathrm{O}_{4}\right)_{3}$, is considerably more compressible than $\mathrm{Ca}_{3} \mathrm{Al}_{2}\left(\mathrm{SiO}_{4}\right)_{3}$, as shown by $\mathrm{X}$-ray diffraction experiments undertaken in a diamond-anvil cell (Olijnyk et al. 1991).

\section{High-temperature behavior and hydrogen loss at $1 \mathrm{~atm}$ of Dora-Maira pyrope}

Dehydroxylation and hydrogen-diffusion behavior were studied at ambient pressure by heating a Dora-Maira pyrope crystal at 1073 and $1323 \mathrm{~K}$ followed by IR measurements (Blanchard and Ingrin 2004a, b). Their crystal was zoned with a rim composition of $\mathrm{Py}_{88} \mathrm{Al}_{9} \mathrm{Gr}_{3}$ and a core composition of $\mathrm{Py}_{81} \mathrm{Al}_{15} \mathrm{Gr}_{3}$. Their results showed that hydrogen associated with the so-called $\mathrm{OH}^{-}$band "triplet" centered at $3651 \mathrm{~cm}^{-1}$ (i.e., the modes at 3641,3651 and $3661 \mathrm{~cm}^{-1}$ ) diffused three times faster than hydrogen associated with the band at $3602 \mathrm{~cm}^{-1}$. This was interpreted as indicating "the presence of two distinct H defects" (Blanchard and Ingrin 2004a, b).

The cluster model permits these experimental results to be interpreted in terms of atomistic-level structure and crystal-chemical considerations. That is, it could be expected that larger hydrogrossular-like clusters containing two or more $\left(\mathrm{H}_{4} \mathrm{O}_{4}\right)^{4-}$ groups behave differently than a single, isolated group at elevated temperatures. The latter could be 
more stable at elevated temperatures (see discussion in Geiger and Rossman 2020b). The experimental high $P-T$ phase relations of grossular-hydrogrossular garnets (Yoder 1950; Pistorius and Kennedy 1960) lend general support to this proposal. Under the assumption that garnet is stoichiometric (12 oxygens), and where the substitution $\left(\mathrm{H}_{4} \mathrm{O}_{4}\right)^{4-} \Leftrightarrow\left(\mathrm{SiO}_{4}\right)^{4-}$ occurs, a local dehydration reaction of the general type may occur at $1 \mathrm{~atm}$ and high $T$ :

$\mathrm{Ca}_{3} \mathrm{Al}_{2} \mathrm{H}_{12} \mathrm{O}_{12}$ (cluster) $\rightarrow \mathrm{Ca}_{3} \mathrm{Al}_{2} \mathrm{O}_{6}$ (tricalcium aluminate) $+6 \mathrm{H}_{2} \mathrm{O}$,

or alternatively an amorphous-like phase could be produced.

To close and on a further note, we propose that the term "hydrogrossular-like cluster" (Geiger and Rossman 2020a, b) describes the crystal-chemical situation better than the term " $\mathrm{OH}^{-}$defect". The latter can be interpreted as indicating that the $\mathrm{H}^{+}$atoms are not an integral part of the garnet structure and that they cannot be described by any crystallographic relationships. We do not think that this is the case. There is solid-solution of the type $\left(\mathrm{H}_{4} \mathrm{O}_{4}\right)^{4-} \Leftrightarrow\left(\mathrm{SiO}_{4}\right)^{4-}$ in garnet, which is most pronounced in grossular and andradite, and its extent is a $f(P, T, X)$ of the system and garnet crystal chemistry.

\section{Conclusions}

There are notable consequences that derive from this research. First, views on crystal chemistry and various experimental results relating to $\mathrm{H}_{2} \mathrm{O}$ incorporation and loss in Dora-Maira pyrope crystals need to be rethought. Second, we think that analytical determinations of $\mathrm{H}_{2} \mathrm{O}$ concentrations in all types of garnet using IR spectroscopy need to consider the precise $\mathrm{OH}^{-}$substitution mechanism for the garnet in question (Bell et al. 1995; Maldener et al. 2003; Reynes et al. 2019). Third, in terms of IR measurements and the study of hydrogen-bearing species (e.g., $\mathrm{H}_{2} \mathrm{O}, \mathrm{OH}^{-}$, $\mathrm{H}^{+}$) in crystals, a full vibrational mode determination is often only possible at the lowest temperatures accessible experimentally. This has been shown in several works on different minerals containing $\mathrm{H}_{2} \mathrm{O}$ and $\mathrm{OH}^{-}$(Kolesov and Geiger 2005; Kolesov 2006; Geiger 2012; Geiger and Rossman 2018) and shown again here. This is because the $\mathrm{H}$ atom can have large amplitudes of vibration at room temperature depending on the local bonding situation. This can lead to substantial mode broadening. Finally, if a given hydrogarnet cluster formed under chemical equilibrium, it must reflect the pressure, temperature, and composition $(P-T-X)$ conditions during crystallization. And here $\mathrm{H}_{2} \mathrm{O}$ activity is important. IR spectroscopy could be of potential use in investigating the petrological conditions under which a garnet, and the rock in which it is contained in, grew. It goes without saying that possible kinetic aspects relating to hydrogarnet cluster formation also need consideration.

Acknowledgements Open access funding provided by the Austrian Science Fund (FWF). We thank Christian Chopin (Paris), once again, for his donation of garnets from Dora Maira that we have used so often for different investigations and George Lager (Louisville-retired) for the synthetic hydrogrossular. Two anonymous reviewers suggested changes for improving the clarity of presentation. This research was supported by a grant from the Austrian Science Fund (FWF: P $30977-$ NBL) to C.A.G. and a NSF grant (EAR-1322082) to G.R.R. C.A.G. also thanks the "Land Salzburg" for financial support through the initiative "Wissenschafts- und Innovationsstrategie Salzburg 2025".

Open Access This article is licensed under a Creative Commons Attribution 4.0 International License, which permits use, sharing, adaptation, distribution and reproduction in any medium or format, as long as you give appropriate credit to the original author(s) and the source, provide a link to the Creative Commons licence, and indicate if changes were made. The images or other third party material in this article are included in the article's Creative Commons licence, unless indicated otherwise in a credit line to the material. If material is not included in the article's Creative Commons licence and your intended use is not permitted by statutory regulation or exceeds the permitted use, you will need to obtain permission directly from the copyright holder. To view a copy of this licence, visit http://creativecommons.org/licenses/by/4.0/.

\section{References}

Aines RD, Rossman GR (1984) The hydrous component in garnets: pyralspites. Am Mineral 69:1116-1126

Armbruster T, Geiger CA, Lager GA (1992) Single crystal X-ray refinement of almandine-pyrope garnets at 298 and $100 \mathrm{~K}$. Am Mineral 77:512-523

Armstrong JT (1995) CITZAF: a package of correction programs for the quantitative electron microbeam X-ray analysis of thick polished materials, thin films, and particles. Microbeam Anal 4:177-200

Avigad D (1992) Exhumation of coesite-bearing rocks in the Dora Maira massif (western Alps, Italy). Geol 20:947-950

Basso R, Cabella R (1990) Crystal chemical study of garnets from metarodingites in the Voltri Group metaophiolites (Ligurian Alps, Italy). Neues Jahrbuch Mineral - Monats 3:127-136

Basso R, Cimmino F, Messiga B (1984) Crystal chemistry of hydrogarnets from three different microstructural sites of a basaltic metarodingite from the Voltri Massif (Western Liguria, Italy). Neues Jahrbuch Mineral - Abh 148:246-258

Bell DR, Rossman GR (1992a) Water in Earth's mantle: The role of nominally anhydrous minerals. Sci 255:1391-1397

Bell DR, Rossman GR (1992b) The distribution of hydroxyl in garnets from the subcontinental mantle of southern Africa. Contrib Mineral Petrol 111:161-178

Bell DR, Ihinger PD, Rossman GR (1995) Quantitative analysis of trace $\mathrm{OH}$ in garnet and pyroxenes. Am Mineral 80:463-474

Beran A (2002) Infrared spectroscopy of micas. In: Micas: Crystal Chemistry and Metamorphic Petrology. Reviews in Mineralogy and Geochemistry. Eds. Mottana A, Sassi FP, Thompson JB, and Guggenheim S, 46:351-369

Birkett TC, Trzcienski WE Jr (1984) Hydrogarnet: Multi-site hydrogen occupancy in the garnet structure. Can Mineral 22:675-680

Blanchard M, Ingrin J (2004a) Kinetics of deuteration in pyrope. Eur J Mineral 16:567-576 
Blanchard M, Ingrin J (2004b) Hydrogen diffusion in Dora Maira pyrope. Phys Chem Mineral 31:593-605

Bosenick A, Geiger CA, Schaller T, Sebald A (1995) A ${ }^{29}$ Si MAS NMR and IR spectroscopic investigation of synthetic pyropegrossular garnet solid solutions. Am Mineral 80:691-704

Bosenick A, Geiger CA, Phillips B (1999) Local Ca-Mg distribution of Mg-rich pyrope-grossular garnets synthesized at different temperatures revealed by ${ }^{29} \mathrm{Si}$ NMR MAS spectroscopy. Am Mineral 42:1422-1433

Bosenick A, Dove MT, Geiger CA (2000) Simulation studies of pyrope-grossular solid solutions. Phys Chem Mineral 27:398-418

Chopin C (1984) Coesite and pure pyrope in high-grade blueschists of the western Alps: a first record and some consequences. Contrib Mineral Petrol 86:107-118

Chopin C, Schertl H-P (1999) The UHP unit in the Dora-Maira Massif, Western Alps. Inter Geol Rev 41:765-780

Compagnoni R, Hirajima T (2001) Superzoned garnets in the coesitebearing Brossasco-Isasca Unit, Dora-Maira massif, Western Alps, and the origin of the whiteschists. Lithos 57:219-236

Dachs E, Geiger CA, Benisek A, Grevel K-D (2012) Grossular: A crystal-chemical, calorimetric, and thermodynamic study. Am Mineral 97:1299-1313

Dawson JB, Stephens WE (1975) Statistical classification of garnets from kimberlite and associated xenoliths. J Geol. 83:598-607

Dilnesa BZ, Lothenbach B, Renaudi G, Wichser A, Kulik D (2014) Synthesis and characterization of hydrogarnet $\mathrm{Ca}_{3}\left(\mathrm{Al}_{\mathrm{x}} \mathrm{Fe}_{1-\mathrm{x}}\right)_{2}\left(\mathrm{SiO}_{4}\right)_{\mathrm{y}}(\mathrm{OH})_{4(3-\mathrm{y})}$. Cement Concrete Res 59:96-111

Farmer VC, Russell JD (1967) Infrared absorption spectrometry in clay studies. Clays Clay Mineral 15:121-142

Ferrando S, Frezzotti ML, Petrelli M, Compagnoni R (2009) Metasomatism of continental crust during subduction: the UHP whiteschists from the Southern Dora-Maira Massif (Italian Western Alps). J Met Geol 27:739-756

Flint EP, McMurdie HF, Wells LS (1941) Hydrothermal and X-ray studies of the garnet-hydrogarnet series and the relationship of the series to hydrations products of Portland cement. Research Paper RP1335. Nat Bur Stand 26:13-33

Gauthiez-Putallaz L, Rubatto D, Hermann J (2016) Dating prograde fluid pulses during subduction by in situ $\mathrm{U}-\mathrm{Pb}$ and oxygen isotope analysis. Contrib Miner Petrol. https://doi.org/10.1007/s0041 0-015-1226-4

Geiger CA (1999) Thermodynamics of $\left(\mathrm{Fe}^{2+}, \mathrm{Mn}^{2+}, \mathrm{Mg}, \mathrm{Ca}\right)_{3} \mathrm{Al}_{2} \mathrm{Si}_{3} \mathrm{O}_{12}$ garnet: An analysis and review. Mineral Petrol 66:271-299

Geiger CA (2008) Silicate garnet: A micro to macroscopic (re)view. Am Mineral 93:360-372

Geiger CA (2012) A low temperature IR spectroscopic investigation of the $\mathrm{H}_{2} \mathrm{O}$ molecules in the zeolite mesolite. Eur J Mineral 24:439-445

Geiger CA, Armbruster T (1997) $\mathrm{Mn}_{3} \mathrm{Al}_{2} \mathrm{Si}_{3} \mathrm{O}_{12}$ spessartine and $\mathrm{Ca}_{3} \mathrm{Al}_{2} \mathrm{Si}_{3} \mathrm{O}_{12}$ grossular garnet: structural dynamic and thermodynamic properties. Am Mineral 82:740-747

Geiger CA, Rossman GR (1994) Crystal field stabilization energies of almandine-pyrope and almandine-spessartine garnets determined by FTIR near infrared measurements. Phys Chem Mineral 21:516-525

Geiger CA, Rossman GR (2018) IR spectroscopy and $\mathrm{OH}^{-}$in silicate garnet: The long quest to document the hydrogarnet substitution. Am Mineral 103:384-393

Geiger CA, Rossman GR (2020a) Nano-size hydrogarnet clusters and proton ordering in calcium silicate garnet: Part I. The quest to understand the nature of "water" in garnet continues. Am Mineral 105:455-467

Geiger CA Rossman GR (2020b) Micro- and nano-size hydrogarnet clusters in calcium silicate garnet: Part II. Mineralogical, petrological and geochemical aspects. Am Mineral 105:468-478
Geiger CA, Langer K, Bell DR, Rossman GR, Winkler B (1991) The hydroxide component in synthetic pyrope. Am Mineral 76:49-59

Geiger CA, Stahl A, Rossman GR (2000) Single-crystal IR- and UV/ VIS-spectroscopic measurements on transition-metal-bearing pyrope: The incorporation of hydroxide in garnet. Eur J Mineral 12:259-271

Geiger CA, Dachs E, Vielreicher N, Rossman GR (2018) Heat capacity behavior of andradite: A multi-sample and -methodological investigation. Eur J Mineral 30:681-694

Gose J, Schmädicke E (2018) Water incorporation in garnet: Coesite versus quartz eclogite from Erzgebirge and Fichtelgebirge. J Petrol 59:207-232

Groppo, C, Ferrando, S, Gilio, M, Botta, S, Nosenzo, F, Balestro, G, Fests A, Rolfo, F (2019) What's in the sandwich? New P-T constraints for the (U)HP nappe stack of southern Dora-Maira Massif (Western Alps) Eur J Mineral 31:665-683.

Guastoni A, Pezzotta F, Superchi M, Demartin F (2001) Pyrope from the Dora Maira Massif, Italy. Gems Gemol 37:198-204

Hirschmann MM, Aubaud C, Withers AC (2005) Storage capacity of $\mathrm{H}_{2} \mathrm{O}$ in nominally anhydrous minerals in the upper mantle. Earth Planet Sci Lett 236:167-181

Hösch A, Langer K (1996) Single crystal MFTIR-spectra at various temperatures of synthetic end member garnets in the $\mathrm{OH}$-valence vibrational region. Phys Chem Mineral 23:305-306

Ingrin J, Skogby H (2000) Hydrogen in nominally anhydrous uppermantle minerals: concentration levels and implications. Eur J Mineral 12:543-570

Khomenko VM, Langer K, Beran A, Koch-Müller M, Fehr T (1994) Titanium substitution and $\mathrm{OH}$-bearing defects in hydrothermally grown pyrope crystals. Phys Chem Mineral 20:483-488

Kobayashi S, Shoji T (1983) Infrared analysis of the grossular-hydrogrossular series. Mineral J 11:331-343

Kolesov BA, Geiger CA (2005) The vibrational spectrum of synthetic hydrogrossular (Katoite) $\mathrm{Ca}_{3} \mathrm{Al}_{2}\left(\mathrm{O}_{4} \mathrm{H}_{4}\right)_{3}$ : A low temperature IR and Raman spectroscopic study. Am Mineral 90:1335-1341

Kolesov BA, Geiger CA (2006) Behavior of $\mathrm{H}_{2} \mathrm{O}$ molecules in the channels of natrolite and scolecite: A Raman and IR spectroscopic investigation of hydrous microporous silicates. Am Mineral 91:1039-1048

Kühberger A, Fehr T, Huckenholz HG, Amthauer G (1989) Crystal chemistry of a natural schorlomite and Ti-andradites synthesized at different oxygen fugacities. Phys Chem Mineral 16:734-740

Li H-Y, Chen R-X, Zheng Y-F, Hu Z (2018) Water in garnet pyroxenite from the Sulu orogen: Implications for crust-mantle interaction in continental subduction zone. Chem Geol 478:18-38

Libowitzky E, Rossman GR (1997) An IR absorption calibration for water in minerals. Am Mineral 82:1111-1115

Liu X-W, Xie Z-J, Wang L, Xu W, Jin Z-M (2016) Water incorporation in garnets from ultrahigh pressure eclogites from Shuanghe Dabieshan. Mineral Mag 80:959-975

Locock AJ (2008) An Excel spreadsheet to recast analyses of garnet into end-member components, and a synopsis of the crystal chemistry of natural silicate garnets. Comp Geosci 34:1769-1780

Lu R, Keppler H (1997) Water solubility in pyrope up to 100 kbar. Contrib Mineral Petrol 129:35-42

Maldener J, Hösch A, Langer K, Rauch F (2003) Hydrogen in some natural garnets studied by nuclear reaction analysis. Phys Chem Mineral 30:337-344

Matsyuk SS, Langer K, Hösch A (1998) Hydroxyl defects in garnets from mantle xenoliths in kimberlites of the Siberian platform. Contrib Mineral Petrol 132:163-179

Mookerjee M, Karato S (2010) Solubility of water in pyrope-rich garnet at high pressures and temperature. Geophy Res Lett 37(L03310):1-5 
Olijnyk H, Paris E, Geiger CA, Lager G (1991) Compressional study of katoite $\left[\mathrm{Ca}_{3} \mathrm{Al}_{2}\left(\mathrm{O}_{4} \mathrm{H}_{43}\right]\right.$ and grossular garnet. J Geophys Res 96:14313-14318

Palke AC, Stebbins JF, Geiger CA, Tippelt G (2015) Cation orderdisorder in Fe-bearing pyrope and grossular garnets: $\mathrm{An}{ }^{27} \mathrm{Al}$ and ${ }^{29} \mathrm{Si}$ MAS NMR and ${ }^{57} \mathrm{Fe}$ Mössbauer spectroscopy study. Am Mineral 100:536-547

Peslier AH (2010) A review of water contents of nominally anhydrous natural minerals in the mantles of Earth, Mars and the Moon. J Volcan Geotherm Res 197:239-258

Pistorius CWFT, Kennedy GC (1960) Stability relations of grossularite and hydrogrossularite at high temperatures and pressures. Am J Sci 258:247-257

Reynes J, Jollands M, Hermann J, Ireland T (2018) Experimental constraints on hydrogen diffusion in garnet. Contrib Mineral Petrol 173:69. https://doi.org/10.1007/s00410-018-1492-z

Rossman GR (2006) Analytical methods for measuring water in nominally anhydrous minerals. Reviews in Mineralogy and Geochemistry. Eds., Keppler H, and Smyth JR, v. 62, 1-28. Mineral Society of America

Rossman GR, Aines RD (1991) The hydrous components in garnets: Grossular-hydrogrossular. Am Mineral 76:1153-1164

Rossman GR, Beran A, Langer K (1989) The hydrous component of pyrope from the Dora Maira Massif, Western Alps. Eur J Mineral $1: 151-154$

Schertl H-P, Schreyer W, Chopin C (1991) The pyrope-coesite rocks and their country rocks at Parigi, Dora Maira Massif, Western Alps: detailed petrography, mineral chemistry and PT-path. Contrib Mineral Petrol 108:1-21

Schertl H-P, Polednia J, Neuser RD, Willner AP (2018) Natural end member samples of pyrope and grossular: A cathodoluminescence-microscopy and -spectra case study. J Earth Sci. https:// doi.org/10.1007/s12583-018-0842-0
Schmädicke and Gose (2019) Low water contents in garnet of orogenic peridotite: clues for an abyssal or mantle-wedge origin? Eur J Mineral 31:715-730

Schmädicke E, Gose J, Reinhardt J, Will T (2015) Garnet in cratonic and non-cratonic mantle and lower crustal xenoliths from southern Africa: Composition, water incorporation and geodynamic constraints. Precam Res 270:285-299

Sharp ZD, Essene EJ, Hunziker JC (1993) Stable isotope geochemistry and phase equilibria of coesite-bearing whiteschists, Dora Maira Massif, western Alps. Contrib Mineral Petrol 114:1-12

Simon G, Chopin C (2001) Enstatite-sapphirine crack-related assemblages in ultrahigh-pressure pyrope megablasts, Dora Maira Massif, western Alps. Contrib Mineral Petrol 140:422-440

Wang L, Zhang Y, Essene EJ (1996) Diffusion of the hydrous component in pyrope. Am Mineral 81:706-718

Withers AC, Wood BJ, Carroll MR (1998) The OH content of pyrope at high pressure. Chem Geol 147:161-171

Yoder HS Jr (1950) Stability relations of grossularite. J Geol 58:221-253

Zechmeister MS, Ferré EC, Cosca MA, Geissman JW (2007) Slow and fast deformation in the Dora Maira Massif, Italian Alps: Pseudotachylytes and inferences on exhumation history. J Struc Geol 29:1114-1130

Xu L, Mei S, Dixon N, Jin Z, Suzuki AM, Kohlstedt D (2013) Effect of water on rheological properties of garnet at high temperatures and pressures. Earth Planet Sci Lett 379:158-165

Zhang B, Li B, Zhao C, Yang X (2019) Large effect of water on Fe-Mg interdiffusion in garnet. Earth Planet Sci Lett 505:20-29

Publisher's Note Springer Nature remains neutral with regard to jurisdictional claims in published maps and institutional affiliations. 